\title{
MINEROGENESIS OF VOLCANIC CAVES OF KENYA ${ }^{3}$
}

\author{
Paolo FORTI ${ }^{1}$, Ermanno GALLI ${ }^{2}$, Antonio ROSSI ${ }^{2}$
}

\begin{abstract}
Kenya is one of the few countries in which karst cavities are scarce with respect to volcanic ones, which are widespread throughout the whole country. The great variability in lava composition allowed the evolution of very different cavities, some of which are amongst the largest lava tubes of the world.

As normal for such a kind of cave, the hosted speleothems and cave minerals are scarce but important from the minerogenetic point of view. Anyway up to present no specific mineralogical research have been carried out therein.

During the 8th International Symposium on Volcanospeleology, held in Nairobi in February 1998, some of the most important volcanic caves of Kenya have been visited and their speleothems and/or chemical deposits sampled: most of them were related to thick guano deposits once present inside these cavities.

Speleothems mainly consisted of opal or gypsum, while the deposits related to guano often resulted in a mixture of sulphates and phosphates.

The analyses confirmed the great variability in the minerogenetic mechanisms active inside the volcanic caves, which consequently allow the evolution of several different minerals even if the total amount of chemical deposit is scarce.

Among the observed minerals kogarkoite, phillipsite and hydroxyapophyllite, must be cited because they are new cave minerals not only for the lava tubes of Kenya, but also for the world cave environment.

The achieved results are compared with the available random data from previous literature in order to allow an updated overview on the secondary cave minerals of Kenya.
\end{abstract}

Keywords: Volcanic caves, Cave minerals, Kenya

\section{RIASSUNTO}

Il Kenya è una delle poche nazioni al mondo in cui le cavità carsiche sono molto meno di quelle vulcaniche, che invece sono comuni e distribuite su tutto il suo territorio. La grande variabilità nella composizione delle rocce effusive dell'area ha permesso l'evoluzione di grotte vulcaniche molto differenti tra loro, alcune delle quali sono tra le grotte laviche più grandi del mondo.

Come già osservato in precedenza anche queste cavità ospitano pochi e piccoli speleotemi che, però, sono molto importanti dal punto di vista delle mineralizzazioni secondarie di grotta. Nonostante ciò sino ad oggi non era stata fatta alcuna ricerca mineralogica sistematica all'interno di queste cavità.

\footnotetext{
1 Istituto Italiano di Speleologia, Università di Bologna.

2 Dipartimento di Scienze della Terra, Università di Modena e Reggio Emilia.

${ }^{3}$ Ricerca effettuata con il supporto finanziario del MURST (ex 60 e $40 \%$ ) e del CNR.
} 
Durante 1' VIII Simposio Internazionale di Vulcanospeleologia, tenutosi a Nairobi nel febbraio del 1998, è stato possibile visitare alcune delle più importanti grotte vulcaniche del Kenya. All'interno di tali cavità sono stati campionati speleotemi e depositi chimici secondari, alcuni dei quali legati all'abbondante quantità di guano un tempo presente al loro interno.

I risultati delle analisi hanno confermato la grande variabilità di meccanismi minerogenetici attivi all'interno delle grotte vulcaniche, che si riflettono, di conseguenza, in una notevole varietà di specie mineralogiche presenti, anche se nel loro insieme i depositi chimici secondari risultano spesso essere di quantità e dimensioni piuttosto scarse. Tra i minerali osservati meritano una menzione particolare la kogarkoite, la phillipsite e la hydroxyapophyllite, descritti per la prima volta al mondo non solo in cavità vulcaniche, ma nelle grotte in generale.

I risultati ottenuti sono stati infine confrontati con quelli già noti in bibliografia per questa area, in modo da fornire un quadro, il più completo possibile ed aggiornato, sui minerali secondari di grotta presenti nelle cavità del Kenya.

Parole chiave: Grotte laviche, Minerali di grotta, Kenya

\section{Introduction}

There has been a growing interest in volcanic caves in the last few years, not only from the explorative point of view but also for the possibility of studying minerogenetic and diagenetic processes absolutely peculiar to this environment (Forti et Al. 1996; Benedetto et Al. 1998).

During an excursion of the 8th International Symposium on Vulcanospeleology, held in Nairobi in February 1998, studies were undertaken to learn more about the minerogenetic processes that develop inside the volcanic cave. One excursionist (P.F.) had the chance to make observations and to take samples in some caves formed in the flank of some of the most important volcanoes.

Kenya is one of the few countries in which karst caves are scarce with respect to volcanic ones, which are widespread throughout the whole country. The great variability in lava composition allowed the evolution of very different caves, some of which are amongst the largest lava tubes of the world.

The collected samples have resulted more or less complete even though only limited to some of the caves visited and essentially, restricted to the small speleothems and efflorescences present on the walls and ceilings as well as to the small masses of whitish substances that had developed inside the once vast guano deposits as there been an extensive cultivation of guano between the 1960's and the1980's (Simons, 1999b).

This has been the first systematic mineralogical research work undertaken in a volcanic cave in this country that have brought about the recognition of many minerals, some of which never been described before now in a cave environment.

The achieved results are compared with the available random data from previous literature in order to allow an updated overview on the secondary cave minerals of Kenya. 


\section{Experimental Methods}

I) First of all an accurate exam of the samples was made by a binocular microscope for detection and separation of the different mineralogical phases.

II) The separated mineralogical phases then underwent a roentgen analysis through a powders diffractometer (Philips PW 1050/25) when the material was quantitatively sufficient and homogeneous or with a Gandolfi camera $(\varnothing 114 \mathrm{~mm}$, exposition time $48 \mathrm{~h}$ ), when the material was scarce or heterogeneous. The following conditions were observed in both cases: $40 \mathrm{Kv}$ tube and $20 \mathrm{~mA}$, radiation $\mathrm{CuKa}, \lambda=1.5418 \AA$, with $\mathrm{Ni}$ filter. Natrolite has been determined by single-crystral precession photographs and a Siemens P4P rotating-anode single-crystal diffractometer (graphite-monochromatized Moka radiation, $52 \mathrm{kV}, 140 \mathrm{~mA}$ ) equipped with XSCANS software (Siemens 1996).

III) The same samples utilised for the diffractometer and the Gandolfi camera also had images made by an electronic microscopic with semi-quantitative chemical analysis through an scanning electronic microscope (SEM Philips XL40) combined to an electronic dispersion microprobe (EDS-EDAX 9900) in the Centro Interdipartimentale Grandi Strumenti (C.I.G.S.) at the University of Modena and Reggio Emilia.

\section{The caves and studied samples}

The three visited areas were: Chyulu Hills, Mount Suswa and Mount Helgon (Forti 1999) (Fig. 1).

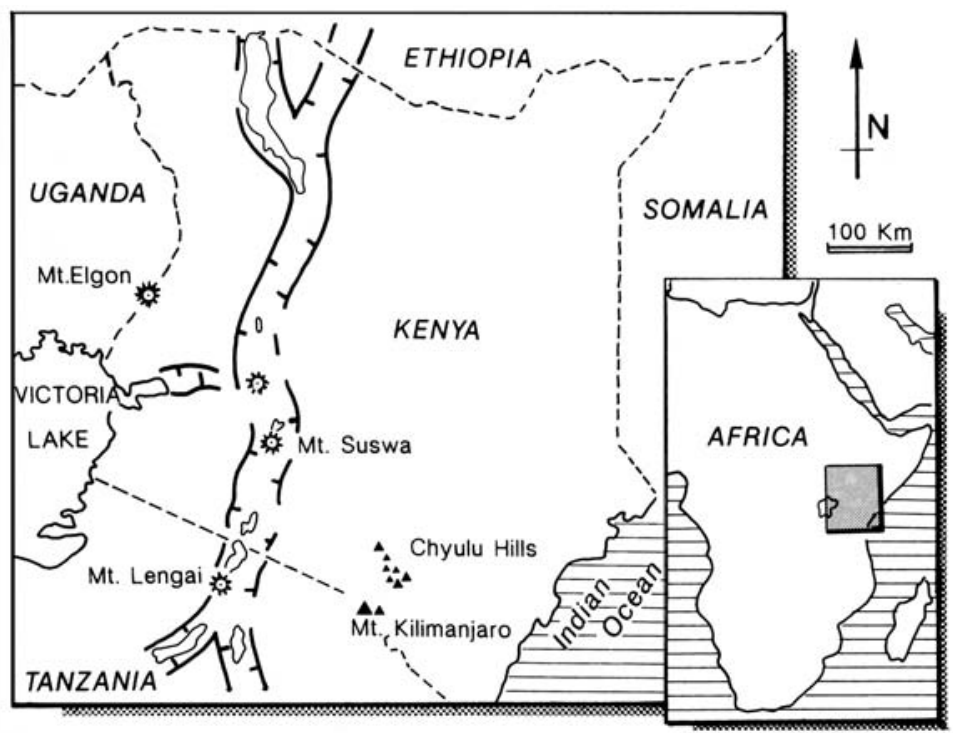

Fig 1-Location map for the volcanic areas in which secondary cave minerals have been sampled for the present study 


\section{Chyulu Hills}

The volcanic area in the Chyulu Hills is located south of Nairobi near the Tanzanian border, practically at the foot of Mount Kilimanjaro, where the volcanic area covers a surface of more than $2000 \mathrm{Km}^{2}$, and peaks up to $2175 \mathrm{~m}$.

\section{MATHAIONI CAVE}

The Mathaioni cave was the first visited: it is one of the largest caves in the area, reaching a development of more than $1.9 \mathrm{~km}$. The cave is developed on two levels and contains lava stalagmites, that could be the largest in the world (and more than three meters high), with some other beautiful re-melting stalagmites. This lava tube was discovered by Jim Simons in the 1960's (Simons, 1974) and was exploited for more than ten years for the imposing deposits of guano it contained, which were three meters thick in some areas.At the moment there is almost no trace of guano in the cave, beside the small puddles of semi-liquid substance present in the lower branches and some earthy whitish coloured deposits of scarce consistence on the cave walls and floors where once there was guano. The sample of these sediments (EG1) under binocular observation has revealed a friable earthy material, light brown in colour, formed by minute prismatic tabular crystals of gypsum (Fig. 2 and Tab. 1a), as confirmed both in the diffractometric and EDAX analyses.

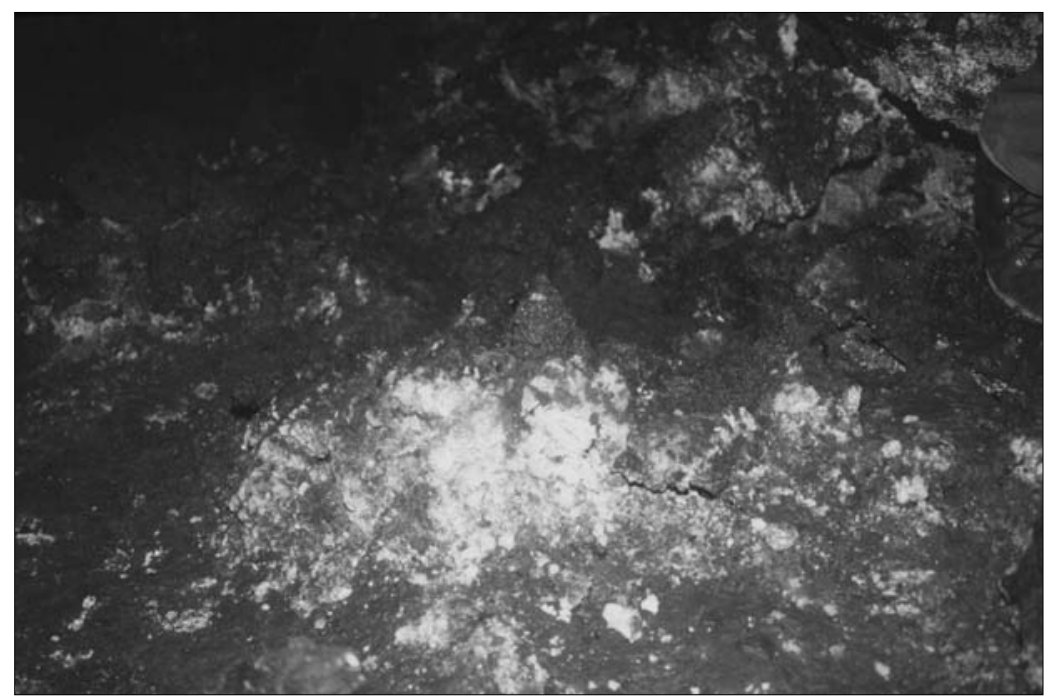

Fig. 2 - Mathaioni cave: white-pale yellow masses, developed at the contact between guano and the cave floor

\section{LEVIATHAN CAVE}

A brief visit to the central sector of the famous Leviathan Cave was organised the next day. This cave was discovered in 1975 and rapidly became the deepest longest 
lava tube in Africa with an extension of $12.5 \mathrm{~km}$ and almost $479 \mathrm{~m}$ difference in level (Simons, 1998). Due to lack of time it was not possible to collect any samples from this cavity also known for the presence of beautiful opal concretions (stalactites and stalagmites) with colours varying from white to yellow (Simons 1998).

\section{SHETANI LAVA CAVE}

The last day of our visit to the Chyulu Hills was spent in the extreme south of the lava outcrop in one of the most famous natural parks of Kenya (Tsavo West) in order to visit the Shetani Lava Cave (Fig. 3). This cave opens into a pahoehoe flow that is quite recent and has a length of about $200 \mathrm{~m}$. It is a sub-horizontal lava tube with a medium of $5 \mathrm{~m}$ in diameter. The cavity has been partially equipped for tourists' visits, basically to protect some bone deposits, where, apart from other things lies an almost complete skeleton of a rhinoceros. No samples were taken in this cave.

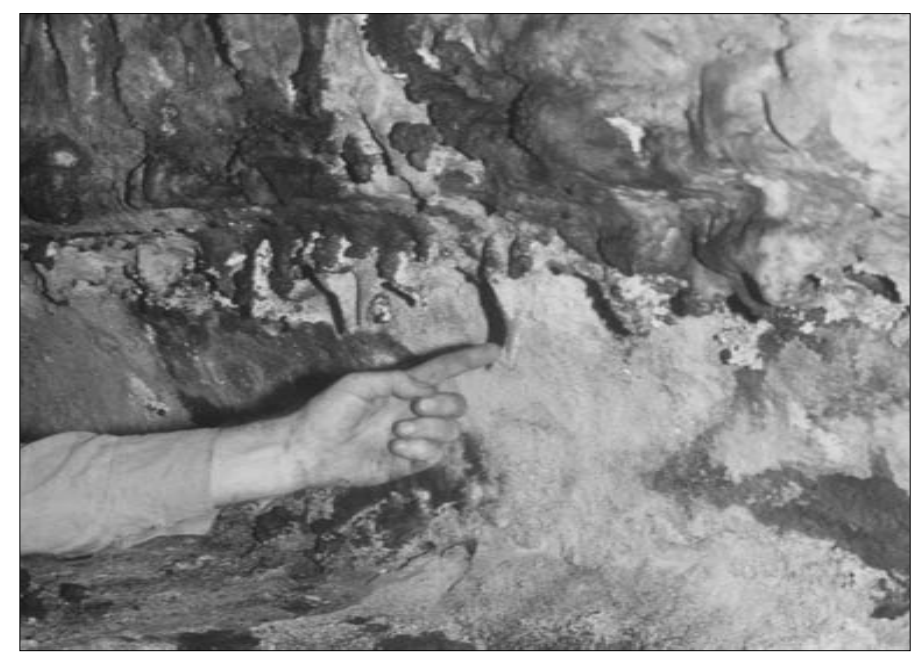

Fig. 3 - Shetani cave: opal formations

\section{MT. Suswa}

The second visited area was the Suswa volcano, which rises imposingly in the centre of the Rift Valley at about $90 \mathrm{~km} \mathrm{~N}$. of Nairobi. The Suswa volcano is characterised by an enormous caldera (some $\mathrm{km}$ in diameter and a depth of more than $200 \mathrm{~m}$ ), whose formation was caused by the collapse of the magmatic chamber. All main caves are found in a lava field on the caldera's NE border. During two days it was possible to visit some of the most important lava tubes in the zone.

\section{CAVE $N^{\circ} 13$}

The entrance displays the remains of a hut constructed in the 50's by the Mau-Mau, during the war of independence. The internal part reveals a marvellous example of 
"lava rope" and strange re-melting forms on the walls: it is also possible to admire some stalactites and there are beautiful translucent needles in a milk white material above a clayey deposit situated in the terminal part of the cavity. Five samples were taken in this cave.

a) EG 4 - It is an elongated fragment of a rope stalactite $(9 \times 3 \mathrm{~cm})$ formed by an earthy material, cream white internally and light-brown and grey externally, very light and arranged in concentric layers with a pealed onion sheeting effect. At large magnification (Tab. 1b) it shows a spongy structure, characterised by the presence of numerous cavities. The X-ray and the chemical analysis have evidenced the presence of opals, which sometimes tend to assume the appearance of octahedron, typical of cristobalite (Tab. 1c).

b) EG6 - A stalactite fragment $(4 \times 1 \mathrm{~cm})$ taken a few meters apart from the previous sample. The fragment consists of an inner core consisting of volcanic rock plenty of small cavities, which are completely covered by a thick layer of a spherulite aggregate made by porcelaneous material, the colour of which is milk white internally and dark nut on the external part. The X-ray and the EDAX analysis have evidenced that the porcelaneous material is formed by amorphous silicate, while in the vacuolar volcanic rock the presence of sanidine has been recognised.

c) EG7-A heterogeneous material, very fragile in hygroscopic, which resulted to be one of the richest of mineralogic species. This sample was taken from the terminal part of the cavity at the top of a clayey deposit. Fragile vitreous lined crusts are present, formed by the evident union of prismatic crystals of thermanonatrite (Tab. 1d), which are only rarely present in isolated individuals (Tab. 1e). There are thin blades of trona $(5 \times 0.3 \mathrm{~mm})$ closely associated to the thermonatrite (Tab. 1f), from colourless to pale yellow, semi-transparent, fibrous-radiate or closely woven in the form of felt. The same sample contained two spheroidal aggregates of minute blade crystals of a pale yellow-orange colour with a glassy brightness. The X-ray and the EDAX analysis have shown it to be kogarkoite (Tab. $1 \mathrm{~g}$ ). Some grains of glass, rounded isolated, with a colour varying from citrine yellow to dark grey, derived from the disintegration of the volcanic rock that forms the cave wall, consist of sanidine.

d) EG8 - Flowstone milk white in colour, very resistant, arranged in millimetre layers that form the floor of the cave in some points. The X-ray and the EDAX analysis have shown the presence of amorphous silicate.

e) EG9- Only a short distance from where the EG4 sample was taken, some aggregates in the form of a rose were removed, and consisted of gypsum blade creamy yellow crystals, partly covered by a thin layer of earthy looking light grey material found to be amorphous silicate.

f) EGII - It's similar to the EG4. This sample is also formed by a lithoid material, sponge-like, very light, with a varying colour from cream white in the central part to dark grey on the external part. The X-ray and the EDAX analysis have shown that also in this case it consists of amorphous silicate. 

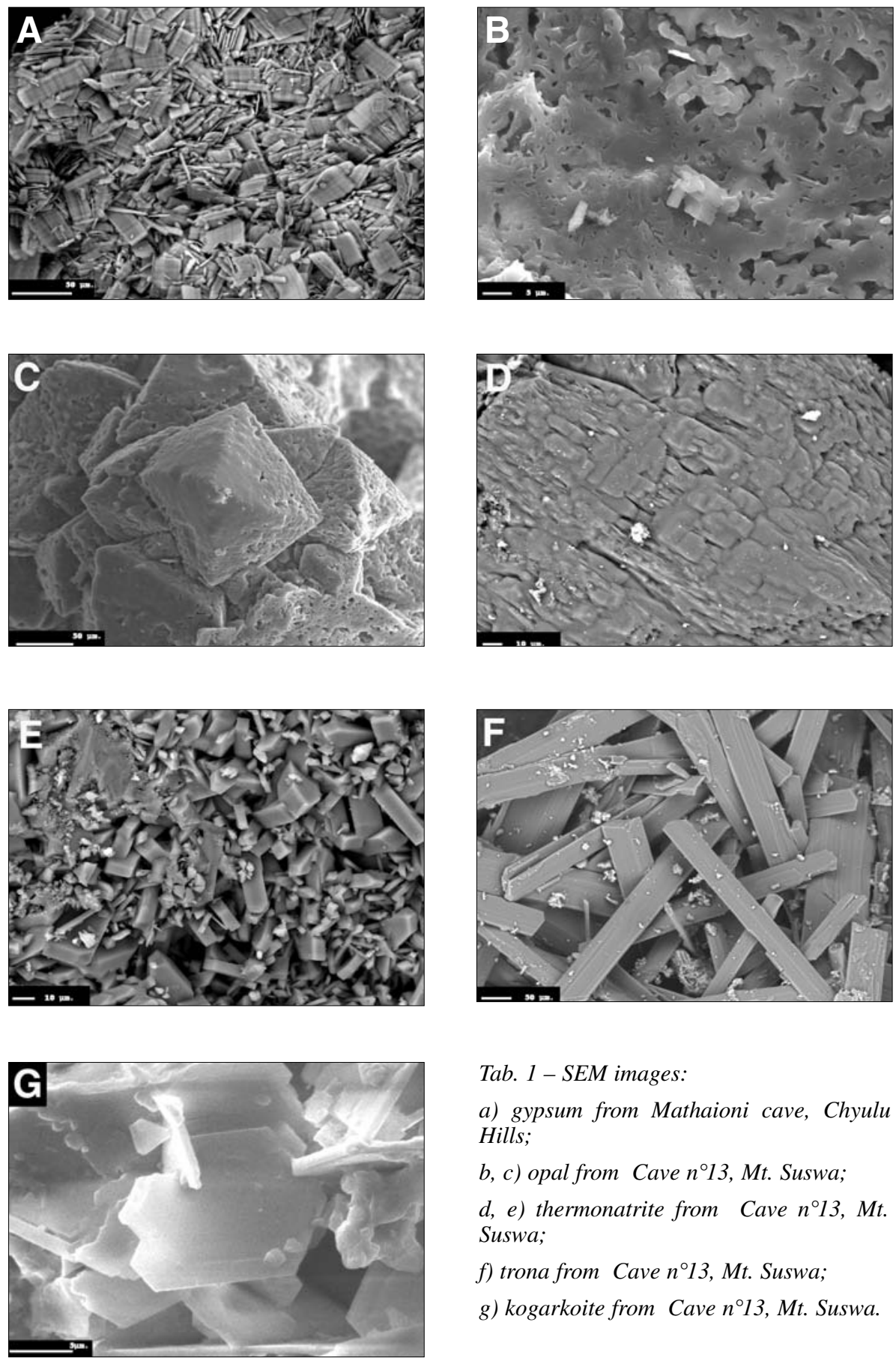

Tab. 1 - SEM images:

a) gypsum from Mathaioni cave, Chyulu Hills;

b, c) opal from Cave $n^{\circ} 13$, Mt. Suswa;

$d$, e) thermonatrite from Cave $n^{\circ} 13, M t$. Suswa;

f) trona from Cave $n^{\circ} 13$, Mt. Suswa;

g) kogarkoite from Cave ${ }^{\circ} 13$, Mt. Suswa. 


\section{CAVE $N^{\circ} 14$}

Famous for a large chamber, "The ballroom", and characterised by a perfectly flat sand and clay floor. This cave had two samples taken and it too, has revealed to be particularly rich in mineralogic phases.

a) EG5A - A coralloid of about $3 \mathrm{~cm}$ in length, formed by a aggregate of spherulitic material from transparent to porcelaneous with an onion-like sheeting cemented by a very resistant light grey earthy material. The X-ray and the EDAX analysis have proved it to be amorphous silica. This material is characterised by the presence of numerous quite spherical cavities where the walls sometimes host minute spheroid aggregates of pseudo-hexagonal blades (Tab. 2a, b) that the X-ray and EDAX have shown to be taranakite.

b) EG5B - This sample consists of numerous sub-spheroids $(0<8 \mathrm{~mm})$ with the surface covered by a heterogeneous material, yellow ochre in colour. By using a binocular microscope it is possible to recognise prismatic bladed crystals of gypsum and prismatic, tabular, colourless, crystals, isolated or in aggregates of few individuals, of hannayite (Tab. 2c). These two minerals are closely associated between them and difficult to separate. The same material has evidenced a small glassy, white or ivory aggregate of radial fibrous crystals of brushite, and a earthy greyish white spheroid knot, consisting of an irregular aggregate of prismatic to tabular crystals of taranakite, more or less altered. The central core of the grains are formed either by a glassy material, ranging from colourless to honey yellow, semi-transparent, apparently compact whereas, in reality it is fractured (Tab. 2d). The X-ray and EDAX analysis have shown it to be newberyite, alone or associated to hydroxylapatite. Sometime small irregular fragments of purple coloured volcanic rock, characterised by the presence of numerous cavities are also present. The X-ray analysis of this last material has shown the presence of sanidine, as also confirmed by the EDAX analysis.

\section{MT. Elgon}

The last visited area was Mount Elgon, situated at $380 \mathrm{~km} \mathrm{NE}$ of Nairobi, on the border between Kenya and Uganda, and its $4360 \mathrm{~m}$ in height make it the third highest peak in the country. This volcano is characterised by scarce lava eruptions and great explosive activity essentially in the Miocene and Pliocene period. The cone is enlarged and basically consists of volcanic ash which then become conglomerate, breccia and tuff. There are numerous caves at the foot of the mountain, ancient lacustrine deposits rich with fossilised trunks, and only partly explored even though the area has been known to the mineralogists for the presence of zeolite in the rock for more than half a century (Udluft,1928; Jèrèmine, 1934). Though these caves developed mainly in volcanic substances, they absolutely can not be considered lava caves; in fact they are the result of water flow erosion caused by their different permeability and cohesion in respect to the overhanging volcanic deposit. Many of them 
have been completely modified by man for the salt extraction. Three of the caves visited were Kitum Cave, Chepnyalil Cave and the Makingen Cave.

\section{KITUM CAVE}

A cave to be visited at daytime in order not to disturb elephants who go there at night to find salts. The vault has numerous cylindrical formed cavities formed by the dissolution of trunks of wood that was originally trapped by the lacustrine sediments. The walls of these cavities sometimes reach to one or two meters in length and a diameter of $40-50 \mathrm{~cm}$; they are generally covered in beautiful calcite crystals and translucid needles of natrolite. Three samples were taken in this cave.

a) EG3A - It is essentially formed by glassy to transparent minute prismatic pseudotetragonal acicular crystals $(5 \times 0.25 \times 0.2 \mathrm{~mm})$, that the X-ray and the EDAX analysis have identified as natrolite (Tab. 2e).

b) EG3B - There are some stalactite fragments (Fig. 4-5) formed by a cylindrical
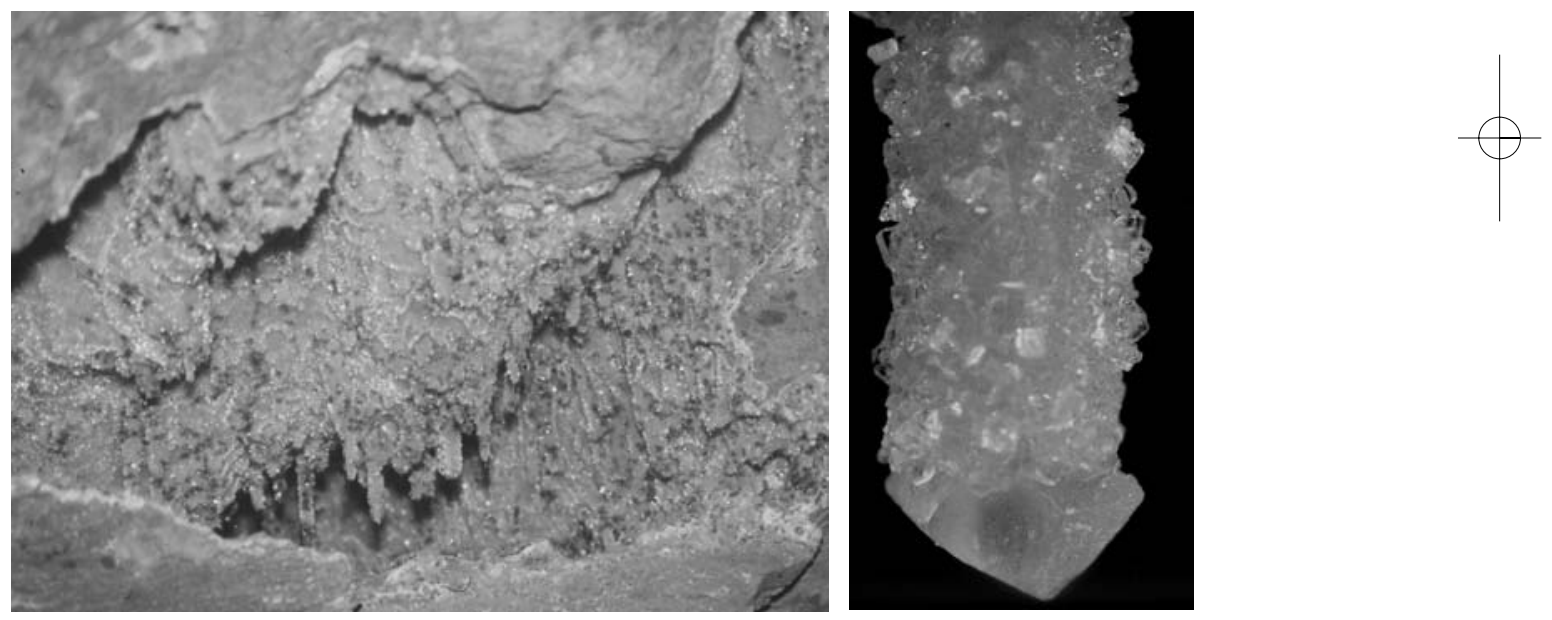

Fig. 4 - Makingen cave: a large cylindrical voids of the ceiling with calcite macrocrystal stalactites covered by natrolite, hydroxylapophyllite and phillipsite.

Fig. 5 -Enlargement of a stalactite of the fig. 4 : it is evident the large calcite crystal on the tip and the natrolite, hydroxylapophyllite and phillipsite aggregates covering its external part.

internal nucleus of golden yellow calcite, wrapped in a thin layer of milk white micro-crystals of phillipsite which is partially covered by transparent prismatic crystals of natrolite. Finally successive crystallisation formed splendid tabular tetragonal prismatic crystals of hydroxyapophyllite over the natrolite. In the same sample there are also beautiful isolated semi-transparent, from colourless to pale golden yellow rhombohedral crystals of calcite $(>10 \mathrm{~mm})$, often associated with a saccharoidal off-white, resistant substance (which proved to be phillipsite) and some earthy grains. 
c) EG3C - The walls on the more internal part of the cave show evident signs of the nightly excavation activity by elephants. This is where aggregates of off-white, sericeous, bending crystals of gypsum (sericolite variety) are found (Fig. 6).

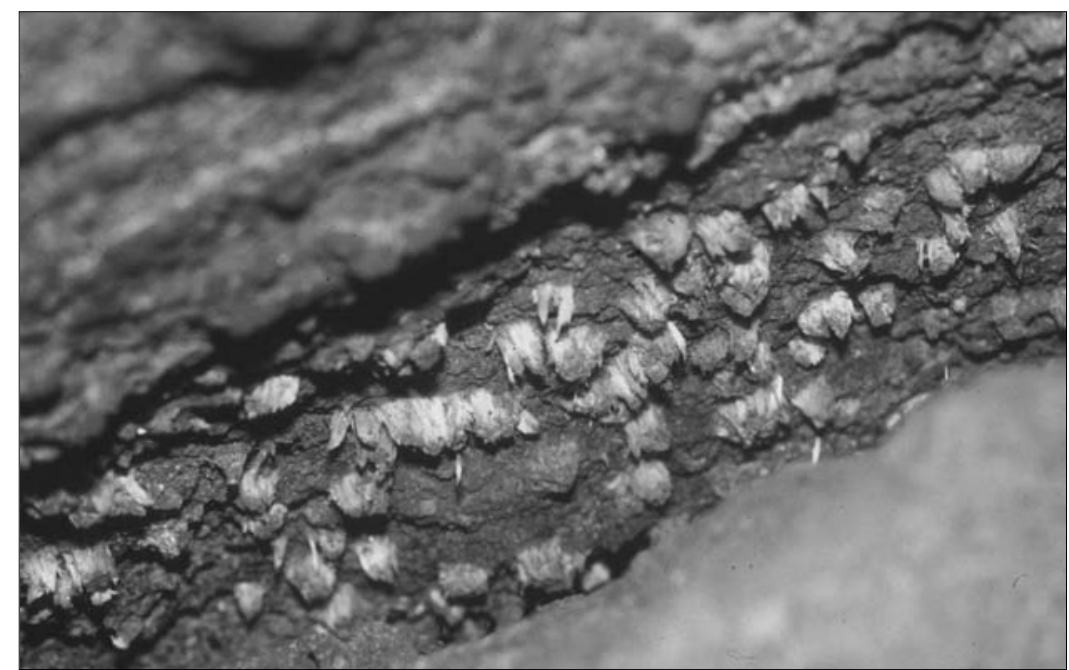

Fig. 6 - Kitum cave: gypsum (sericolite variety) inside a crack in the cave bottom.

All the described samples have inside small fragments of volcanic rock, the colour of which varying from pinkish- purple to dark grey, characterised by the presence of vacuole with walls covered in a thin layer of twinned crystals of phillipsite. In some cases the phillipsite crystals are covered by hemispheric masses or minute cubic crystals of halite (Tab. 2f), whereas in others the presence of an irregular spreading of celestite has been identified (Tab. $2 \mathrm{~g}$ ).

\section{CHEPNYALIL CAVE}

A cave of great archaeological interest due to the rock paintings on the walls near the large entrance while the flooring is literally covered in crude bone and rock utensils and even, though less frequent, ceramic fragments. The wall provided a rock fragment of a pseudo-cylindrical shape $(8 \times 5 \mathrm{~cm})$ made of splendid prismatic crystals, glassy, light brown in colour, isolated or weakly plaited to natrolite on the surface or again strongly cemented to become a highly resistant and compact underneath. Tabular crystals of hydroxyapophyllite are present in the interstice, almost always covered over by a thin rosy-white glaze.

\section{MAKINGEN CAVE}

The last cave visited was the Makingen Cave, which is located about a $\mathrm{km}$ from the last one. The entrance to the cave is extremely spectacular with a $60 \mathrm{~m}$ wide mouth 

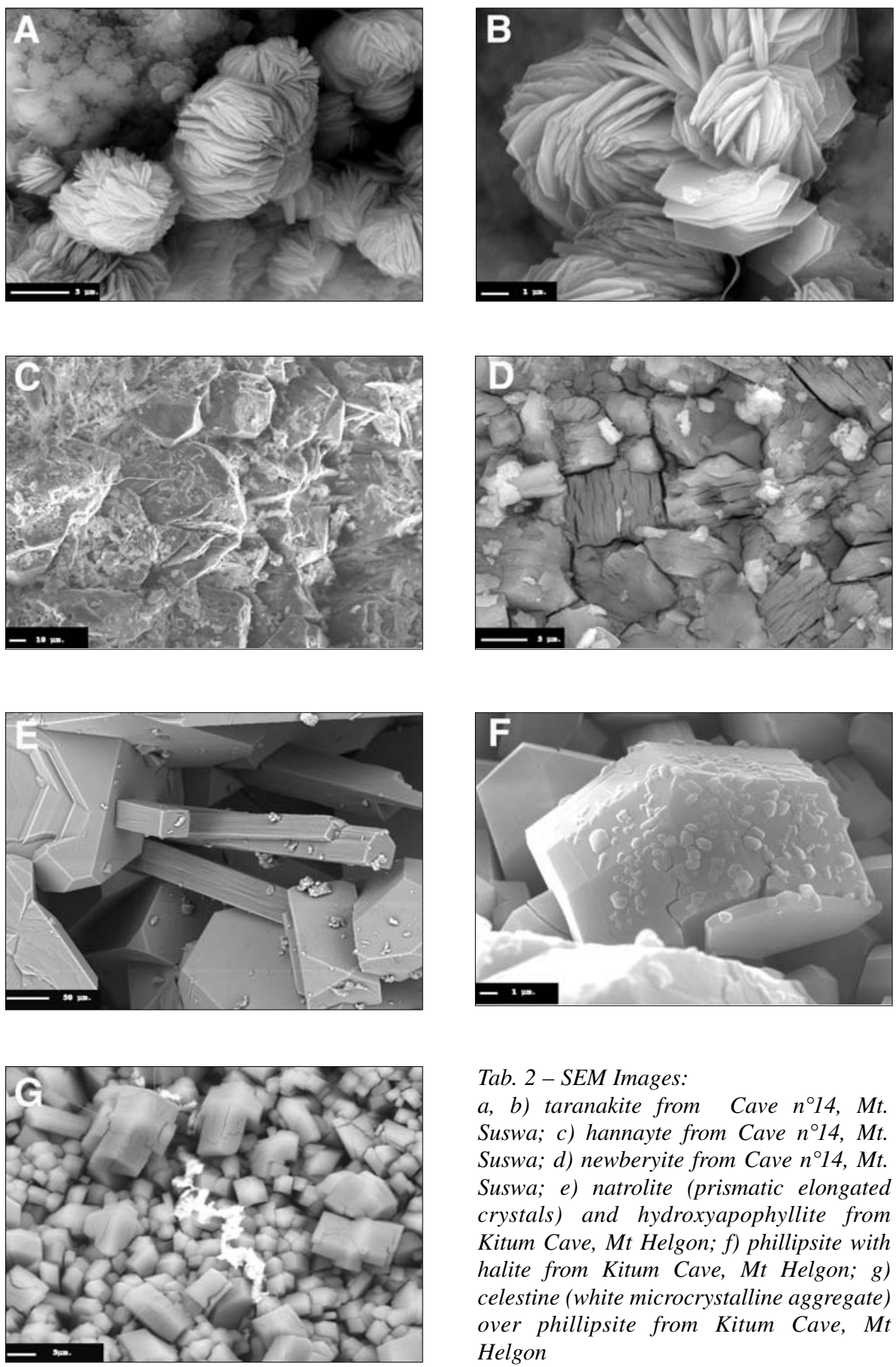

Tab. 2 - SEM Images:

$a$, b) taranakite from Cave $n^{\circ} 14, M t$. Suswa; c) hannayte from Cave $n^{\circ} 14, \mathrm{Mt}$. Suswa; d) newberyite from Cave $n^{\circ} 14, \mathrm{Mt}$. Suswa; e) natrolite (prismatic elongated crystals) and hydroxyapophyllite from Kitum Cave, Mt Helgon; f) phillipsite with halite from Kitum Cave, Mt Helgon; g) celestine (white microcrystalline aggregate) over phillipsite from Kitum Cave, Mt Helgon 
and 16-18 in height, with a perennial waterfall. The erosive action of the water is much more evident in this cave and the principal tunnels remind us of the normal karst ones. There is a great accumulation of fallen masses at the end of the cave similar to those present in the Kitum Cave. The bat colonies are much more numerous in this part of the cavity to those observed in the other cavities. No sample has been taken in this cave.

\section{Discussion}

Only 8 of the many secondary minerals noted in the volcanic caves of Kenya (Tab. 3) were not found in the samples analyzed in the present study, more precisely: apophyllite, aragonite, bobierrite, mendozite, mirabilite, sodium alum, thenardite and tetranatrolite. It must be said that two of these, thenardite and tetranatrolite, have been described only recently (Kashima \& Ogawa, 1998) in samples taken during the same excursion in other areas but in the same caves from which those described here came from. This fact confirmed what was mentioned in the introduction about the sample collection: it was reasonably accurate but certainly the lack of time at disposition did not allow enough time to carefully observe all the secondary chemical deposits in the visited caves.

Thenardite observed by Kashima and Ogawa is probably a product from the dehydration of mirabilite, a mineral that was already known in the lava caves of Kenya (Sutcliffe1973, Simons 1998).

Among the other minerals undetected in the present study, the absence of composts like sodium alum, mirabilite and mendozite can be easily justified by the fact that the samples were taken in a period just successive to a heavy rainfall and therefore it seems reasonable that these very soluble sulphates have been completely washed away by the percolation water.

Moreover the removal of almost all the guano present in the cave for an economic exploitation is probably the reason why the bobierrite was not observed.

The aragonite described by Simons (1998) was not found simply because during the excursion there was insufficient time to get to the area where the mineral had been seen.

The last minerals not found in the present study are tetranatrolite and apophyllite, but it is highly probable that these two silicates correspond to natrolite and hydroxyaphopyllite of this paper. Morphological and X-ray diffraction analyses cannot discriminate between natrolite and tetranatrolite, which has also been recently discredited by the Subcommittee on Zeolite Mineral Nomenclature of the IMA Committee on NEW Minerals and Mineral Names (Coombs et al., 1997; Artioli \& Galli, 1999): discrimination may be done only by means of chemical and single crystal diffraction analyses. During the present study several pseudo-tetragonal vitreous, perfectly transparent crystals have been selected from fragments of the stalactites as well as from fragment of rock of the walls of the Kitum Cave. They have been analysed with a single-crystal precession camera and single crystal diffractometer: always they resulted natrolite, which was also confirmed by the chemical analysis. 
Tab. 3. The secondary minerals in volcanic caves of Kenya : an asterisk in the first column identifies the minerals observed in the present study

\begin{tabular}{|c|c|c|c|c|c|}
\hline & Mineral & Chemical Formula & Crystal System & $\begin{array}{l}\text { Habit or mode of } \\
\text { occurrence I }\end{array}$ & References \\
\hline & Apophyllite & $\mathrm{KCa}_{4}\left[\mathrm{Si}_{8} \mathrm{O}_{20}(\mathrm{~F}, \mathrm{Na}, \mathrm{OH})\right] \cdot 8 \mathrm{H}_{2} \mathrm{O}$ & Hexagonal & Prismatic crystal & Udluft (1928) \\
\hline & Aragonite & $\mathrm{CaCO}_{3}$ & orthorhombic & Small clusters of flowers & Simons (1998) \\
\hline & Bobierrite & $\mathrm{Mg}_{3}\left(\mathrm{PO}_{4}\right)_{2} \cdot 8 \mathrm{H}_{2} \mathrm{O}$ & monoclinic & $\begin{array}{l}\text { Small radiating acicular } \\
\text { crystals }\end{array}$ & Simons $(1974,1976)$ \\
\hline$*$ & Brushite & $\mathrm{CaH}\left(\mathrm{PO}_{4}\right) \cdot 2 \mathrm{H}_{2} \mathrm{O}$ & monoclinic & $\begin{array}{l}\text { Radial aggregates } \\
\text { of thin needles }\end{array}$ & \\
\hline * & Calcite & $\mathrm{CaCO}_{3}$ & trigonal & $\begin{array}{l}\text { Rhombohedral crystals, } \\
\text { stalactites, stalagmites }\end{array}$ & $\begin{array}{l}\text { Udluft (1928), } \\
\text { Jérémine (1934), } \\
\text { Sutcliffe ( 1973) }\end{array}$ \\
\hline * & Celestine & $\mathrm{Sr} \mathrm{SO}_{4}$ & orthorhombic & Small zig-zag shaped coating & \\
\hline & Collophane II & $\mathrm{Ca}_{5}\left(\mathrm{PO}_{4}\right)_{3}(\mathrm{OH}, \mathrm{F}, \mathrm{Cl})$ & amorphous & Secondary stalactites & Simons (1998) \\
\hline * & Gypsum & $\mathrm{Ca} \mathrm{SO}_{4} \cdot 2 \mathrm{H}_{2} \mathrm{O}$ & monoclinic & $\begin{array}{l}\text { Bladed or acicular } \\
\text { curved crystals }\end{array}$ & $\begin{array}{l}\text { Simons (1974), } \\
\text { Kashima \& Ogawa (1998) }\end{array}$ \\
\hline$*$ & Halite & $\mathrm{NaCl}$ & cubic & Small spots or cubic crystals & \\
\hline * & Hannayite & $\mathrm{Mg}_{3}\left(\mathrm{NH}_{4}\right)_{2} \mathrm{H}_{4}\left(\mathrm{PO}_{4}\right)_{4} \cdot 8 \mathrm{H}_{2} \mathrm{O}$ & triclinic & Transparent prismatic crystals & \\
\hline * & Hydroxyapophyllite & $\mathrm{KCa}_{4} \mathrm{Si}_{8} \mathrm{O}_{20}(\mathrm{OH}) \cdot 8 \mathrm{H}_{2} \mathrm{O}$ & tetragonal & Tetragonal prismatic crystal & \\
\hline * & Hydroxylapatite & $\mathrm{Ca}_{5}\left(\mathrm{PO}_{4}\right)_{3}(\mathrm{OH})$ & hexagonal & Small plate-like masses & \\
\hline * & Kogarkoite & $\mathrm{Na}_{3} \mathrm{FSO}_{4}$ & monoclinic & $\begin{array}{l}\text { Aggregates of small } \\
\text { bladed crystals }\end{array}$ & \\
\hline & Mesolite ${ }^{\text {III }}$ & $\mathrm{Na}_{2} \mathrm{Ca}_{2}\left[\mathrm{Al}_{6} \mathrm{Si}_{9} \mathrm{O}_{30}\right] \cdot 8 \mathrm{H}_{2} \mathrm{O}$ & orthorhombic & Prismatic crystals & Udluft (1928) \\
\hline & Mesotype (=natrolite & $\mathrm{Na}_{2}\left[\mathrm{Al}_{2} \mathrm{Si}_{3} \mathrm{O}_{10}\right] \cdot 2 \mathrm{H}_{2} \mathrm{O}$ & orthorhombic & & Jérémine (1934) \\
\hline & Mirabilite & $\mathrm{Na}_{2} \mathrm{SO}_{4} \cdot 10 \mathrm{H}_{2} \mathrm{O}$ & monoclinc & $\begin{array}{l}\text { Cuved crystals, } \\
\text { efflorescences }\end{array}$ & $\begin{array}{l}\text { Sutcliffe (1973), } \\
\text { Simons (1998) }\end{array}$ \\
\hline & Mendozite & $\mathrm{Na} \mathrm{Al}\left(\mathrm{SO}_{4}\right)_{2} \cdot 16 \mathrm{H}_{2} \mathrm{O}$ & monoclinc & Blisters & Sutcliffe(1973), \\
\hline & & & & & Simons $(1998,1999 a)$ \\
\hline * & Natrolite & $\mathrm{Na}_{2}\left[\mathrm{Al}_{2} \mathrm{Si}_{3} \mathrm{O}_{10}\right] \cdot 2 \mathrm{H}_{2} \mathrm{O}$ & orthorhombic & Prismatic crystals & $\begin{array}{l}\text { Udluft (1928), } \\
\text { Sutcliffe( 1973) }\end{array}$ \\
\hline * & Newberyite & $\mathrm{Mg} \mathrm{HPO}_{4} \cdot 3 \mathrm{H}_{2} \mathrm{O}$ & orthorombic & $\begin{array}{l}\text { Plate-like masses of } \\
\text { fractured crystals }\end{array}$ & \\
\hline$*$ & Opale & $\mathrm{Si} \mathrm{O}_{2} \cdot \mathrm{nH} 2 \mathrm{O}$ & amorphous & Stalactites, Stalagmites & Simons $(1974,1998)$ \\
\hline * & Phillipsite & $\mathrm{K}_{2}\left(\mathrm{Ca}_{0.5}, \mathrm{Naa}\right)_{4}\left[\mathrm{Al}_{6} \mathrm{Si}_{10} \mathrm{O}_{32}\right] \cdot 12 \mathrm{H}_{2} \mathrm{O}$ & $\begin{array}{l}\text { monoclinic } \\
\text { pseudo-orthohombic }\end{array}$ & $\begin{array}{l}\text { Pseudo-tetragonal } \\
\text { twinned crystals }\end{array}$ & \\
\hline & Sodium Alum & $\mathrm{Na} \mathrm{Al}\left(\mathrm{SO}_{4}\right) \cdot 12 \mathrm{H}_{2} \mathrm{O}$ & cubic & Efflorescences & Simons (1998) \\
\hline * & Taranakite & $\mathrm{H}_{6} \mathrm{~K}_{3} \mathrm{Al}_{5}\left(\mathrm{PO}_{4}\right)_{8} \cdot 18 \mathrm{H}_{2} \mathrm{O}$ & trigonal & $\begin{array}{l}\text { Nodule of prismatic } \\
\text { bladed crystals }\end{array}$ & \\
\hline & Tetranatrolite & $(\mathrm{Na}, \mathrm{Ca})_{16}\left[\mathrm{Al}_{19} \mathrm{Si}_{21} \mathrm{O}_{80}\right) \cdot 16 \mathrm{H}_{2} \mathrm{O}$ & tetragonal & White acicular frostwork & Kashima \& Ogawa(1998) \\
\hline * & Thermonatrite & $\mathrm{Na}_{2} \mathrm{CO}_{3} \cdot \mathrm{H}_{2} \mathrm{O}$ & orthorhombic & Thin crusts of prismatic crystals & \\
\hline & Thenardite & $\mathrm{Na}_{2} \mathrm{SO}_{4}$ & orthorhombic & Pale yellowish soft cave powder & Kashima \& Ogawa(1998) \\
\hline * & Trona & $\mathrm{Na}_{3} \mathrm{H}\left(\mathrm{CO}_{3}\right)_{2} \cdot 2 \mathrm{H}_{2} \mathrm{O}$ & monoclinic & Thin blade-shaped laths & \\
\hline
\end{tabular}

Notes: ${ }^{\mathrm{I}}$ In italics those from this work; II Term used for massive fine-grained members of the apatite group, usually carbonate-fluorapatite or carbonate-hydroxylapatite; III M.H.Hey (1931) abstracting the Udluft's paper writes "The author terms the calciferous material mesolite, but his optical data show it to be natrolite". 
The same may be said of apophyllite (Udluf, 1928), moreover it has to be noted that this term is assigned to a entire group of minerals, among which there is hydroxyapophyllite, the detection of which may be sure only by mean of chemical analyses.

It should be noted that the results of the present study, even though only limited to some caves has allowed to identify 12 minerals which are described for the first time in the caves of Kenya (Tab.3). This fact is surely indicative of the great minerogenetic interest of these caves and also suggests the idea that research in this field is still far from being concluded.

Five of the minerals observed for the first time are phosphates (brushite, hannayite, hydroxylapatite, newberyite and taranakite), each have already been noted in the cave environment: all of them are clearly related to the great guano deposits. Some of these minerals have certainly already been sampled in lava caves of Kenya, but studies carried out on them (Simons, 1998) were clearly insufficient to discriminate them.

The presence of such a high number of phosphates even after the deposits of guano have been almost destroyed when it was sold as fertiliser (Simmons 1999), leads to believe that probably, if a detailed study was conducted on these deposits before their reduction, the number of cave minerals in the lava cave of Kenya would have been much more.

The cave n.13 on Mount Suswa provided three of the minerals observed for the first time during this study: thermonatrite, trona and kogarkoite.

Thermonatrite and trona were already known cave minerals, especially in the volcanic caves (Hill \& Forti 1997) and their genesis should be related to weathering of the lava flow. Instead, the kogarkoite has been noted for the very first time in a cave environment and its genesis is, however, probably similar to that of other two associated minerals: in fact their anions cations can all derive from the weathering of volcanic rock though the presence of $\mathrm{F}$ and $\mathrm{S}$ could, in this case, be put in relation to the presence of guano deposits.

The last four minerals observed for the first time in Kenya (phillipsite, hydroxyapophyllite, celestina and halite) have all been noted in samples taken from the Kitum Cave on Monte Helgon.

The genesis of all these minerals is to be put in relation of the weathering effect from the percolation waters inside the volcanic breccia and tuff in which the cave developed. The rainwater seepage, in fact, was easy inside the breccia and tuff because they have trapped large tree trunks that, as a result of their permanence before destruction, have left oblong imprints, often connected between them (Fig.4).

Phillipsite and hydroxyapophyllite are silicates widespread in the volcanic rocks but they are here reported, for the first time in the world, as cave minerals.

In this case their environment of development is so particular as to identify them as real and true cave minerals. In fact, these two minerals together with natrolite form 
the external structure of some macro-crystalline calcite stalactites (Fig. 5). Their genesis and evolution are probably related to the first moment of seepage of rainwater inside the still warm volcanic rock; the fluids in fact, may have permitted the mobilisation of ions necessary for the formation of these minerals and for their successive deposits inside the spaces generated by the decomposition of trapped trees.

\section{Final Remarks}

Although the sample collecting was of course performed in a hurry and incomplete, the present paper offered the possibility to increase the relative knowledge about secondary minerals developed in the lava caves of Kenya, now being 22 .

It must be remembered that the sample collection and therefore the study of minerals has only regarded a small part of the volcanic caves actually known in Kenya, so it is fairly probable that the real number of secondary minerals truly present is much superior and so new and systematic research should be conducted in the caves of this country.

Considering the twelve minerals observed for the first time in these caves, note that 3 (hydroxyaphophyllite, kogarkoite and phillipsite) result in being completely new to the caves in general.

This would confirm what has only recently been brought to light and that is, though at first sight the volcanic caves lack secondary chemical deposits, they are among the underground environment more important for the formation of secondary mineralization.

Hopefully an international team will be settled up in the near future in order to coordinate researches and studies on genetic processes and mechanisms allowing the development of secondary mineralization inside the volcanic caves.

\section{Acknowledgments}

Our thanks to Sig. J.W.E. Simons and all the Cave Exploration Group of East Africa for the help provided during the sample collection, Dr. Massimo Tonelli of Centro Interdipartimentale Grandi Strumenti dell'Università di Modena e Reggio Emilia for the precious help given in the use of the electronic microscope.

\section{REFERENCES}

ARTIOLI G., GALLI E., 1999, Gonnardite: Re-examination of Holotype material and discreditation of tetranatolite, Amer. Mineral., 84, 1445-1450.

BENEDETTO C., FORTI P., GALLI E., ROSSI A., 1998, Chemical deposits in volcanic caves of Argentina, Proc. $8^{\text {th }}$ Int. Symp. on Vulcanospeleology, Int. J. Speleol., 27B (1/4), 155-162.

COOMBS D.S., ALBERTI A., ARMBRUSTER T., ARTIOLI G., COLELLA C., GALLI E., GALLI E., GRICE J.D., LIEBAU F., MANDARINO J.A., MINATO H., NICKEL E.H., PASSAGLIA E., PEACOR D.R., QUARTIERI S., RINALDI R., ROSSM., SHEPPARDD R.H., TILLMANNS E., VEZZALINI G. (1997) Recommended nomenclature for zeolite miner- 
als: report of the subcommittee on zeolite of International Mineralogical Association, Commission on New Minerals and Mineral Names, Canad. Mineral., 35, 1571-1606.

DAVIES G.J., 1999, “Hades" a Remarkable Cave on Oldoinyo Lengai in the East African Rift Valley, Proc. $8^{\text {th }}$ Int. Symp. on Vulcanospeleology, Int. J. Speleol., 27B (1/4), 57-67.

FORTI P., 1994, Cave minerals in Volcanic Caves, Atti I Encontro Int. de Vulcanoespeleologia das Ilhas Atlanticas, Terceira, Acores, 1992, 91-98.

FORTI P., 1998, Le Grotte Laviche del Kenya, Sottoterra, 105, 46-55.

FORTI P., PANZICA LA MANNA M., ROSSI A., 1996, The peculiar mineralogical site of the Alum cave (Vulcano, Sicily), $7^{\text {th }}$ Int. Symp. on Vulcanospeleology, Canarie 1994, 35- 44.

FORTI P., GIUDICE G., MARINO A., ROSSI A., 1996 The MC1 cave on the Mt. Etna and its peculiar metastable speleothems, 7 th Int. Symp. On Vulcanospeleology, Canarie 1994, 33.

GLOVER P.E., GLOVER E.C., TRUMP E.C., WATERIDGE L.E.D.,1964, The Lava Caves of Mount Suswa, with Particular Reference to their Ecological Role, Studies in Speleology, 1(1), 51-67.

HEY M.H., 1931, Abstract of the paper Zeolithe als Fossilisationsmaterial by H. Udluft, Mineral. Abstr. (1931), 4 (1-4), 374.

JEREMINE E., 1934, Note sur les zéolites des Monts Lubur et du Mont Elgon, Bull. Soc. Franc Minéral., 57, 240-243.

KASHIMA N., OGAWA T., 1998, Speleo-minerals in Volcanic Caves of Kenya, East African Rift Zone, J. Speleol. Soc. Japan, 23, 46-52.

SIEMENS, 1996, XSCANS: X-ray Single Crystal Analysis System - Technical reference, Siemens instruments.

SIMONS J.W.E., 1974, The lava caves of the northern Chyuly Hill, Kenya, Studies in Speleology, 2 (6), 238-255.

SIMONS J.W.E., 1976, Leviathan Cave, a Major Lava Tube in Kenya, BCRA Bull., 14, p.23-25.

SIMONS J.W.E., 1998, Volcanic Caves of Kenya. A guide for the $8^{\text {th }}$ Int. Symp, on Vulcanospeleology. Nairobi, Kenya, February 1998, 37 pp.

SIMONS J.W.E., 1999a, Volcanic caves of East Africa. An overview, Proc. $8^{\text {th }}$ Int. Symp. on Vulcanospeleology, Int. J. Speleol., 27B (1/4), 11-20.

SIMONS J.W.E., 1999b, Guano mining in kenyan lava tunnel-caves, Proc. $8^{\text {th }}$ Int. Symp. on Vulcanospeleology, Int. J. Speleol., 27B (1/4), 33-51.

SUTCLIFFE A.J., 1973, Caves of the East African Rift Valley, Trans. Cave Res. Group of G.B., 15 (1), 41-65.

UDLUFT H., 1928, Zeolithe als Fossilisationsmaterial, Arrkiv Kemi Min. Geol., 9 (33), 15 pp., 2pls.

Received: 10 october 2003

Accepted: 30 november 2003 